MARTA UlbRYCH

Uniwersytet Ekonomiczny w Krakowie, Polska

\title{
Znaczenie przemysłu w gospodarce i polityce regionalnej Unii Europejskiej
}

\author{
The importance of industry in the economy \\ and the regional policy of the European Union
}

\begin{abstract}
Streszczenie: Współczesna gospodarka globalna oraz towarzyszące jej niezwykle dynamiczne przyspieszenie rozwoju technologicznego wyrażają się między innymi w wypieraniu cywilizacji industrialnej na korzyść gospodarki opartej na wiedzy i informacji. Tendencje te mają swoje odzwierciedlenie w malejącej roli przemysłu zarówno w zatrudnieniu, jak i tworzeniu PKB w większości krajów europejskich. Ponadto Unia Europejska jest silnie zróżnicowana pod względem dotychczasowego uprzemysłowienia oraz warunków i perspektyw rozwoju przemysłu w przyszłości. Poprawa warunków ramowych dla przemysłu oraz wspieranie możliwości wzrostu produkcji i zatrudnienia w przemyśle stanowią poważne wyzwania w świetle dotychczasowej trajektorii rozwojowej. Równocześnie znaczenia nabierają działania podejmowane na poziomie regionalnym. Celem opracowania jest diagnoza stanu i procesów rozwoju przemysłu w gospodarce regionalnej Unii Europejskiej oraz warunkujących go czynników. Uwaga zostaje także zwrócona na rolę polityki regionalnej w promowaniu programów przekształceń i rozwoju przemysłu.
\end{abstract}

\begin{abstract}
The contemporary global economy and the accompanying extremely dynamic acceleration of technological development are expressed, among other things, in the displacement of the industrial civilization in favor of an economy based on knowledge and information. These trends are reflected in the decreasing role of industry in both employment and GDP in most European Union countries. Moreover, the EU is highly diverse in terms of current industrialisation and conditions and prospects for the development of industry in the future. Improving the framework conditions for industry and promoting opportunities for growth in production and employment in the industry are the major challenges in the light of the current developmental trajectory. At the same time the importance of the actions taken at the regional level increases. The aim of the study is to diagnose the condition and processes of industrial development in the regional economy of the EU and the factors determining it. Attention is also paid to the role of regional policy in promoting industry transformations and development programs.
\end{abstract}

Słowa kluczowe: dysproporcje regionalne; industrializacja; polityka regionalna; przemysł

Keywords: regional disparities; industrialization; industry; regional policy 


\section{WSTĘP}

Struktura gospodarki Unii Europejskiej rozwija się zgodnie z ogólnoświatowym trendem zwiększania udziału usług w generowaniu PKB kosztem sektora produkcyjnego. Wkład przemysłu w tworzenie PKB systematycznie spada od lat 80 . XX wieku, działalność przemysłowa zmniejsza także swój udział w zakresie aktywizacji zasobów pracy. Aktualne tendencje w gospodarce światowej, ze spowolnieniem tempa wzrostu gospodarczego i presją konkurencji międzynarodowej na czele, podkreślają jednak konieczność stworzenia odpowiednich warunków wspierających długofalowy wzrost i rozwój przemysłu europejskiego. Zwraca się przy tym uwagę na podstawowe funkcje przemysłu w zakresie generowania wzrostu gospodarczego i zatrudnienia. W dobie przemysłów bazujących na potencjale kapitału ludzkiego projektowanie i wytwarzanie innowacyjnych towarów przemysłowych w oparciu o nowe technologie stanowi podstawę w tworzeniu dla Europy przewagi konkurencyjnej. Przyjęta w 2010 roku Strategia na rzecz inteligentnego i zrównoważonego rozwoju sprzyjającego włączeniu społecznemu podkreśla, że źródłem wzrostu gospodarczego ma być gospodarka oparta na wiedzy, przyjazna środowisku naturalnemu i efektywnie wykorzystująca dostępne zasoby. Dla realizacji przyjętych priorytetów przygotowano siedem inicjatyw, w tym także projekt zatytułowany Zintegrowana polityka przemysłowa $w$ erze globalizacji. Konkurencyjność i zrównoważony rozwój na pierwszym planie (KOM [2010] 2020). Priorytetowe znaczenie przemysłu dla wzrostu gospodarki UE i wyjścia z kryzysu zostało także podkreślone w przyjętej w październiku 2012 roku strategii reindustrializacji UE zatytułowanej Silniejszy przemyst europejski na rzecz wzrostu i ożywienia gospodarczego. Aktualizacja komunikatu w sprawie polityki przemystowej (COM [2012] 582 final). Zakłada ona zwiększenie udziału produkcji przemysłowej w tworzeniu unijnego PKB do 20\% w 2020 roku w stosunku 15,5\% w 2011 roku. Wspomniane strategie akcentują siłę i znaczenie przemysłu UE oraz eksponują konieczność wzmocnienia konkurencyjności bazy produkcyjnej Unii. Koncentracja uwagi Komisji Europejskiej na wypracowaniu ramowych uregulowań gospodarczych osadzonych w społecznej gospodarce rynkowej i uwzględniających aspekty środowiskowe ma uzasadnienie w potrzebie skoordynowanych działań w zakresie przemysłu pomiędzy państwami członkowskimi i synergii różnych obszarów polityki Unii.

Stymulowanie zmian przemysłowej struktury wytwarzania oraz kreowanie warunków dla poprawy konkurencyjności przedsiębiorstw przemysłowych jest oczywiście domeną polityki przemysłowej. Omawiając jednak uwarunkowania dla rozwoju przemysłu w Unii Europejskiej, trzeba mieć na uwadze nie tylko politykę przemysłową, która polega na bezpośredniej ingerencji władz publicznych w sferę przemysłu, ale także inne polityki i zasady funkcjonowania Unii ${ }^{1}$. Ponadto UE jest silnie zróżnicowana pod względem dotychczasowego uprzemysłowienia, a adaptacja przedsiębiorstw przemysłowych do nowych warunków gospodarowania wymaga uwzględnienia specyfiki terytorialnej. Wydaje się zatem zasadne

${ }^{1} \mathrm{~W}$ ramach ogólnej polityki gospodarczej można wyróżnić dziedziny, które pośrednio bądź bezpośrednio oddziałują na przemysł. Klasyfikację w tym zakresie prezentuje m.in. opracowanie: Pelkmans, J. (2006). European Industrial Policy. Bruges European Economic Policy Briefings (BEEP) briefing, 15. Pozyskano z https://www. coleurope.eu/sites/default/files/research-paper/beep15.pdf. 
przeanalizowanie możliwości oddziaływania europejskiej polityki regionalnej² na mobilizowanie aktywności przemysłowej, tym bardziej że nowa polityka spójności i dostępne w jej ramach fundusze są identyfikowane jako narzędzie wspierające innowacyjny przemysł poprzez kształtowanie korzystnych warunków infrastrukturalnych i społeczno-gospodarczych podnoszących atrakcyjność jednostek terytorialnych dla lokalizacji działalności gospodarczej.

\section{ZRÓŻNICOWANIE UPRZEMYSŁOWIENIA UNII EUROPEJSKIEJ}

NA POZIOMIE REGIONALNYM

Przemiany potencjału produkcyjnego w UE związane są ze zmianą sposobu produkcji przemysłowej, jej restrukturyzacją oraz relokacją działalności przemysłowej do krajów o relatywnie niższych kosztach pracy. Zastosowanie pracooszczędnych technologii i wzrost wydajności pracy prowadzą nieuchronnie do zmiany charakteru i struktury przemysłowej. Opisywane zjawiska w różnym stopniu dotyczą poszczególnych gospodarek i regionów, co zależne jest od fazy ich rozwoju oraz stopnia powiązań międzynarodowych.

Stopień uprzemysłowienia poszczególnych terytoriów opisują trzy podstawowe wskaźniki: wartość produkcji sprzedanej, wartość produkcji dodanej brutto oraz liczba pracujących w przemyśle. W niniejszym opracowaniu do określenia poziomu uprzemysłowienia regionów Unii Europejskiej wykorzystano wartość dodaną brutto w przemyśle znormalizowaną przez liczbę ludności. Przyjmując założenie o trwałości ukształtowanych struktur przemysłowych, analizę przeprowadzono w ujęciu statycznym, a dostępne dane dla 2010 roku zagregowano na poziomie NUTS 2. Takie podejście metodologiczne uwzględnia tendencje występujące od połowy lat 70. XX wieku w gospodarce światowej, w efekcie których maleje rola tradycyjnych przemysłów pracochłonnych na rzecz przemysłów nowoczesnych o zaawansowanej technologii, wytwarzających i przetwarzających wiedzę, czyli naukowochłonnych, cechujących się wyższą wartością dodaną (Wieloński, 1998).

Analiza terytorialnego zróżnicowania stopnia uprzemysłowienia poszczególnych regionów UE wyraźnie rysuje dominację ośrodków północnej Szwecji, południowo-zachodniej Finlandii, południowej Irlandii, zachodnich i południowych Niemiec, Austrii, Beneluksu oraz północnych Włoch. Obszarami o relatywnie wysokiej koncentracji działalności przemysłowej są ponadto regiony Wielkiej Brytanii, środkowej Francji i północnej Hiszpanii (ryc. 1) ${ }^{3}$. Niski poziom lokalizacji przemysłu odnotowano natomiast w regionach Europy

\footnotetext{
${ }^{2}$ Terminologia dotycząca tej sfery interwencji UE posługuje się zamiennie pojęciem polityki regionalnej (podstawowa cześć interwencji zorientowana jest na wspieranie rozwoju regionalnego) i polityki spójności (celem interwencji jest redukowanie dysproporcji w gospodarkach układów terytorialnych UE).

${ }^{3}$ Inne badania prezentujące zróżnicowanie przestrzenne potencjału przemysłowego w poszczególnych regionach UE dają podobne wyniki. Do ich przeprowadzenia użyto miernika syntetycznego obejmującego dwa składowe mierniki empiryczne: liczbę pracujących oraz wartość dodaną brutto. Analizą objęto lata 1996 i 2005, co pozwala określić tendencję w zakresie rozmieszczenia przemysłu. Przy czym wyniki dla 2005 roku wykazują niewielkie zmiany względem 1996 roku, co świadczy o trwałości ukształtowanych struktur (Rachwał, Wiederman, Kilar, 2009).
} 
Środkowo-Wschodniej, co podkreśla różnice rozwojowe między „starymi” i „nowymi” członkami UE. Wyjątek stanowią jedynie regiony Czech.

Porównując terytorialny rozkład poziomu PKB per capita w UE, można dostrzec korelację między stopniem uprzemysłowienia a poziomem rozwoju (ryc. 2). Regiony, gdzie przemysł odgrywa dużą rolę, są jednocześnie najbardziej rozwiniętymi gospodarczo częściami UE. Rozkład ten pozwala ponadto wyodrębnić regiony konwergencji, czyli kwalifikujące się do wsparcia w ramach funduszy polityki regionalnej UE, które są wyłaniane na podstawie poziomu PKB per capita.

Stan uprzemysłowienia oraz aktualna struktura przestrzenna przemysłu w UE jest wynikiem historycznego procesu rozwoju, który je stymulował bądź hamował. Przestrzeń Europy podlega bowiem procesom „długiego trwania”, czego dowodem jest zbieżność struktur współcześnie obserwowanych w UE z ich kształtem z początków ubiegłego tysiąclecia. Wówczas rdzeń Europy rozciągał się od południowo-wschodniej Anglii do północnych Włoch, ciągnąc się łukiem wzdłuż Renu. Ten tzw. Europejski Pentagon, obejmujący ponadto na zachodzie Paryż, a na wschodzie Hamburg i Monachium, wyróżnia się także na aktualnej mapie UE. Na uwagę zasługują w tym kontekście kraje skandynawskie, które jako północne peryferia Europy sprzed tysiąca lat zdołały zbliżyć się do jej rdzenia względem poziomu rozwoju społeczno-gospodarczego (Gorzelak, 2007).

Istniejąca dyspersja rozwoju poszczególnych obszarów staje się jednym z podstawowych wyzwań UE. Fakt ten znajduje odzwierciedlenie w raportach analizujących zróżnicowanie poziomu rozwoju społeczno-gospodarczego wewnątrz Unii (m.in. Barca, 2009). Jednocześnie podkreśla się konieczność podjęcia działań i zapewnienia warunków umożliwiających zmniejszenie skali tego zróżnicowania przestrzennego w ramach polityki regionalnej.

\section{UWARUNKOWANIA ROZWOJU PRZEMYSŁU W REGIONACH UNII EUROPEJSKIEJ}

Lokalizacja produkcji przemysłowej jest tradycyjnie zdeterminowana występowaniem zasobów naturalnych i pracy oraz zaplecza infrastrukturalnego dla przemysłu. Działalność oparta na lokalnych zasobach jest istotnym elementem wspierającym trwały rozwój, ponieważ są to zasoby endogeniczne. Istotnym czynnikiem warunkującym rozwój przemysłu jest także dobrze rozwinięte zaplecze infrastrukturalne, czyli infrastruktura transportowa i gospodarcza oraz infrastruktura społeczna, która ma szczególną wartość w przypadku przemysłów zaawansowanych technologicznie. Poprawa atrakcyjności inwestycyjnej umożliwia także większą aktywność kapitału zewnętrznego, który z kolei jako nośnik postępu technicznego odgrywa zasadniczą rolę $\mathrm{w}$ technologicznej modernizacji regionu.

Duże znaczenie przemysłu w gospodarce zależy obecnie od jego międzynarodowej konkurencyjności i aktywności innowacyjnej, która umożliwia unowocześnienie struktury rzeczowej produkcji. Istotna jest nie tylko tradycyjnie optymalna alokacja już istniejących czynników produkcji, ale tworzenie nowych zasobów specyficznych dla danego regionu. 


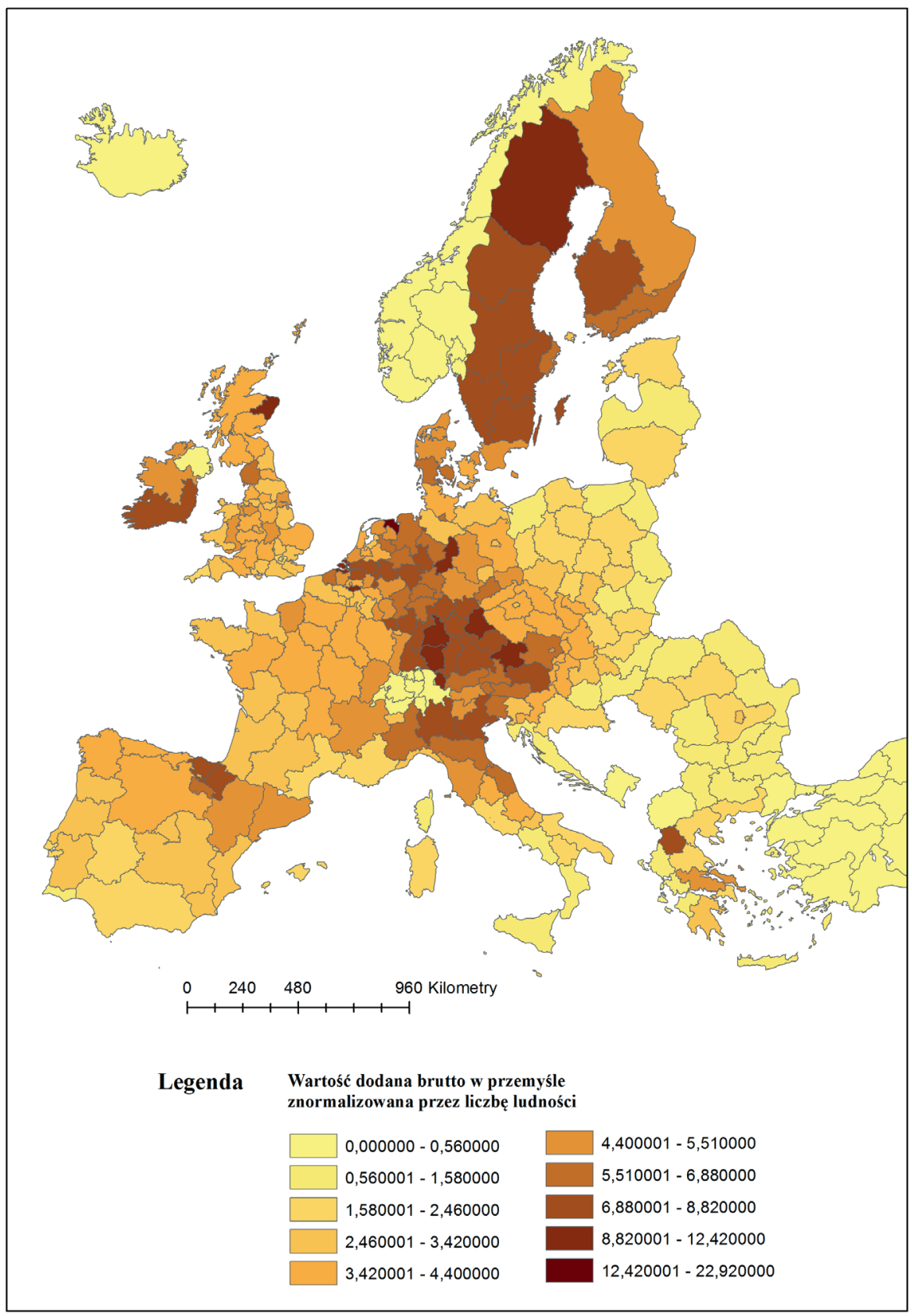

Ryc. 1. Regionalny rozkład natężenia działalności przemysłowej w Unii Europejskiej na poziomie NUTS 2 w 2010 roku

Źródło: opracowanie własne na podstawie danych Eurostatu (2013, 30 listopada). Gross value added at basic prices by NUTS 3 regions oraz Population on 1 January by age and sex - NUTS 2 regions; pozyskano z http://epp. eurostat.ec.europa.eu/ 


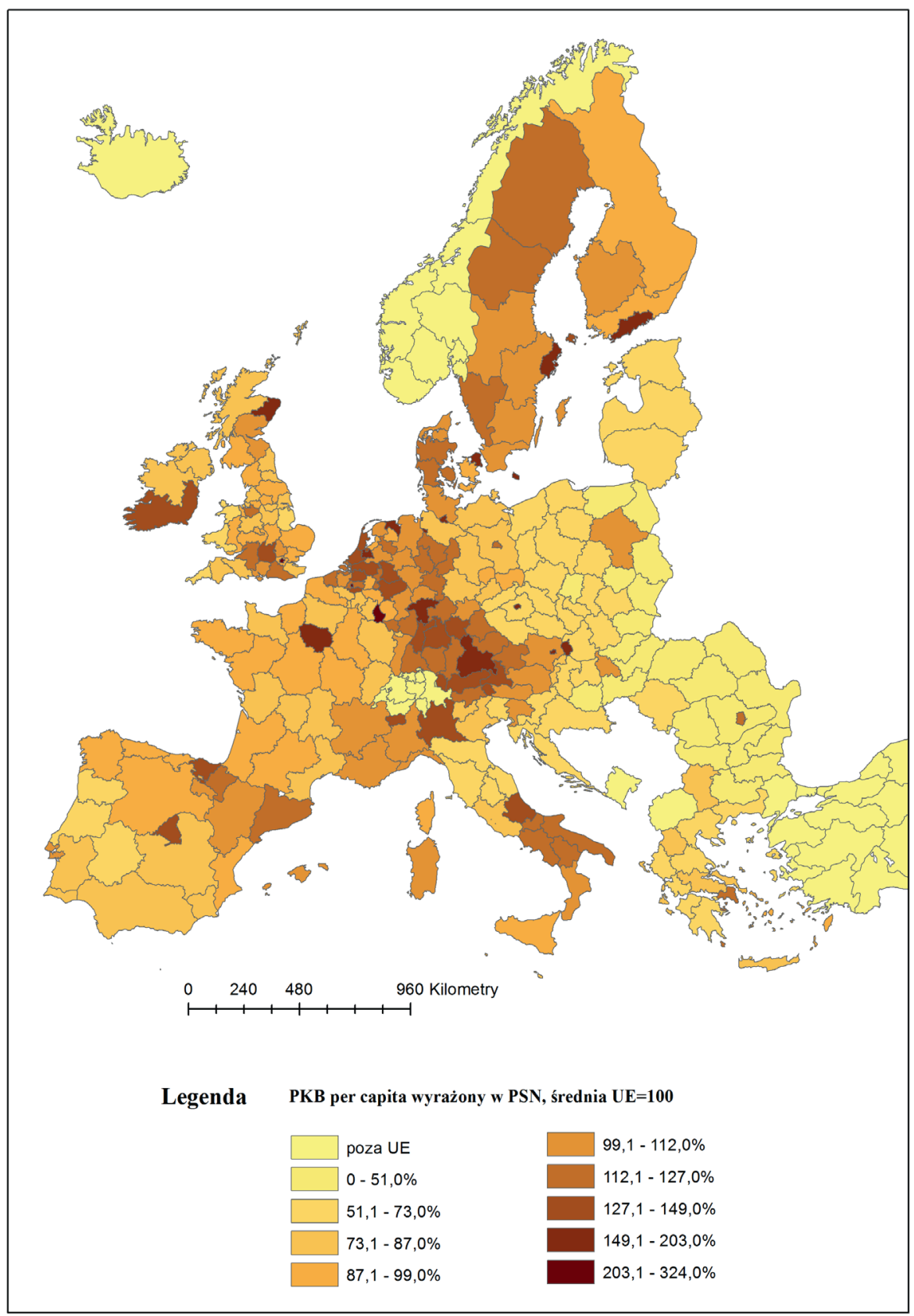

Ryc. 2. Regionalny rozkład poziomu PKB per capita w Unii Europejskiej na poziomie NUTS 2 w 2010 roku, średnia UE $=100$

Źródło: opracowanie własne na podstawie danych Eurostatu (2013, 30 listopada). Regional gross domestic product (PPS per inhabitant in \% of the EU27 average) by NUTS 2 regions; pozyskano z http://epp.eurostat.ec.europa.eu/ 
Innowacje są kluczowe dla podtrzymania wzrostu produkcji przede wszystkim na obszarach rozwiniętych gospodarczo. W przypadku regionów słabszych ważna jest zdolność wykorzystania przewag konkurencyjnych i reorientacja produkcji przemysłowej w kierunku wytwarzania produktów o wyższej wartości dodanej. Działania ukierunkowane na te cele pozostają w bezpośrednim związku z wydatkami na badania i rozwój $(\mathrm{B}+\mathrm{R})$ oraz poziomem wykształcenia kapitału ludzkiego, które decydują o stopniu innowacyjności i tym samym konkurencyjności danego regionu. Strategia na rzecz inteligentnego i zrównoważonego rozwoju sprzyjającego włączeniu społecznemu podkreśla ponadto, że jedyną możliwą reakcją na skutki kryzysu gospodarczego, starzenie się społeczeństwa i zmiany klimatyczne jest intensyfikacja procesów innowacyjnych w UE.

Tab. 1. Wybrane wskaźniki dla najbardziej uprzemysłowionych regionów UE w 2010 roku

\begin{tabular}{|l|l|c|c|c|c|}
\hline Region NUTS 2 & Państwo & $\begin{array}{c}\text { Wartość dodana } \\
\text { brutto (tys. euro } \\
\text { na mieszkańca) }\end{array}$ & $\begin{array}{c}\text { PKB } \\
\text { per capita } \\
\text { (średnia UE } \\
\text { =100) }\end{array}$ & $\begin{array}{c}\text { Wydatki na } \\
\text { B+R (euro na } \\
\text { mieszkanca) }\end{array}$ & $\begin{array}{c}\text { Kapitał ludzki } \\
\text { w sektorze } \\
\text { nauki i techniki } \\
\text { (\% ludności } \\
\text { czynnej } \\
\text { zawodowo) }\end{array}$ \\
\hline Groningen & Holandia & 22,92 & 180 & 891,2 & 49,5 \\
\hline $\begin{array}{l}\text { North Eastern } \\
\text { Scotland }\end{array}$ & $\begin{array}{l}\text { Wielka } \\
\text { Brytania }\end{array}$ & 12,42 & 162 & 612,4 & 46,3 \\
\hline Övre Norrland & Szwecja & 11,72 & 126 & 962,0 & 42,2 \\
\hline Stuttgart & Niemcy & 11,11 & 144 & 1808,5 & 45,9 \\
\hline Vorarlberg & Austria & 10,24 & 135 & 548,3 & 33,5 \\
\hline Zeeland & Holandia & 9,82 & 123 & 248,0 & 39,9 \\
\hline Braunschweig & Niemcy & 9,76 & 115 & 2517,3 & 38,3 \\
\hline Tübingen & Niemcy & 9,63 & 124 & 1659,2 & 45,6 \\
\hline Oberösterreich & Austria & 9,63 & 126 & 917,4 & 41,3 \\
\hline Oberpfalz & Niemcy & 9,11 & 122 & b.d. & b.d. \\
\hline $\begin{array}{l}\text { Prov. Brabant } \\
\text { Wallon }\end{array}$ & Belgia & 9,09 & 131 & 2557,4 & 61,0 \\
\hline Karlsruhe & Niemcy & 8,82 & 132 & 1533,2 & 42,6 \\
\hline Niederbayern & Niemcy & 8,77 & 117 & b.d. & 35,5 \\
\hline $\begin{array}{l}\text { Southern and } \\
\text { Eastern }\end{array}$ & Irlandia & 8,69 & 145 & 669,8 & 44,6 \\
\hline
\end{tabular}

b.d. - brak danych

Źródło: opracowanie własne na podstawie mapy nr 1 i 2 oraz danych Eurostatu (2013, 30 listopada). Total intramural R\&D expenditure (GERD) by sectors of performance and NUTS 2 regions oraz Human resources in science and technology (HRST) by NUTS 2 regions; pozyskano $\mathrm{z}$ http://epp.eurostat.ec.europa.eu/

Innowacje $\mathrm{z}$ największym prawdopodobieństwem pojawią się w regionach o dużym potencjale, czyli wysoko rozwiniętych. Dane zebrane w tabeli 1 wskazują, że regiony o dużej roli przemysłu utrzymują także wiodącą pozycję pod względem poziomu wydatków na $\mathrm{B}+\mathrm{R}$, co widoczne jest przede wszystkim w regionach niemieckich. Obszary te są bardziej konkurencyjne dzięki większej innowacyjności i lepszej infrastrukturze oraz możliwości 
łatwiejszego dostępu do edukacji i wykwalifikowanych pracowników. Mogą się one także pochwalić stosunkowo wysokim odsetkiem osób zatrudnionych w sektorze nauki i techniki, średnio na poziomie 43,5\% ludności czynnej zawodowo.

Cechą charakterystyczną regionów o niskiej stopie koncentracji przemysłu jest natomiast niewielki poziom wydatków na $\mathrm{B}+\mathrm{R}$, średnio na poziomie 31 euro na mieszkańca (tab. 2).

Tab. 2. Wybrane wskaźniki dla najsłabiej uprzemysłowionych regionów w 2010 roku

\begin{tabular}{|l|l|c|c|c|c|}
\hline Region NUTS 2 & Państwo & $\begin{array}{c}\text { Wartość } \\
\text { dodana brutto } \\
\text { (tys. euro na } \\
\text { mieszkańca) }\end{array}$ & $\begin{array}{c}\text { PKB } \\
\text { per capita } \\
\text { (średnia } \\
\text { UE=100) }\end{array}$ & $\begin{array}{c}\text { Wydatki na } \\
\text { B+R (euro na } \\
\text { mieszkańca) }\end{array}$ & $\begin{array}{c}\text { Kapitał ludzki } \\
\text { w sektorze } \\
\text { nauki } \\
\text { i techniki } \\
\text { \% ludności } \\
\text { czynnej } \\
\text { zawodowo) }\end{array}$ \\
\hline Ionia Nisia & Grecja & 0,56 & 76 & 13,9 & 20,8 \\
\hline Severoiztochen & Bułgaria & 0,69 & 36 & 8,8 & 28,2 \\
\hline Severozapaden & Bułgaria & 0,72 & 26 & 3,7 & 24,7 \\
\hline Severen tsentralen & Bułgaria & 0,74 & 29 & 4,0 & 28,1 \\
\hline Voreio Aigaio & Grecja & 0,82 & 70 & 71,1 & 24,2 \\
\hline Algarve & Portugalia & 0,86 & 83 & 76,2 & 23,5 \\
\hline Yuzhen tsentralen & Bułgaria & 0,87 & 30 & 7,6 & b.d \\
\hline Nord-Est & Rumunia & 0,88 & 29 & 10,1 & 22,2 \\
\hline Lubelskie & Polska & 1,05 & 42 & 42,0 & 31,7 \\
\hline Yugoiztochen & Bułgaria & 1,07 & 36 & 8,4 & b.d \\
\hline Yugozapaden & Bułgaria & 1,13 & 75 & 52,3 & 40,7 \\
\hline Notio Aigaio & Grecja & 1,14 & 107 & 37,8 & 16,3 \\
\hline Podlaskie & Polska & 1,16 & 45 & 21,9 & 32,2 \\
\hline Calabria & Włochy & 1,21 & 65 & 75,5 & 29,2 \\
\hline
\end{tabular}

b.d. - brak danych

Źródło: opracowanie własne na podstawie mapy nr 1 i 2 oraz danych Eurostatu (2013, 30 listopada). Total intramural R\&D expenditure (GERD) by sectors of performance and NUTS 2 regions i Human resources in science and technology (HRST) by NUTS 2 regions; pozyskano z http://epp.eurostat.ec.europa.eu/

Skala zróżnicowania wydatków na B+R wśród najlepiej i najsłabiej uprzemysłowionych regionów podkreśla rozpiętość między wartościami skrajnymi, które różnią się blisko 700-krotnie. Najniższy poziom wydatków w tym obszarze występuje w regionach bułgarskich. W przypadku zasobów kapitału ludzkiego w sektorze nauki i techniki różnice są nieporównywalnie mniejsze, średnio znajduje w nim zatrudnienie 26,8\% ludności czynnej zawodowo. Zestawienie to podkreśla, że możliwości rozwoju regionów problemowych ograniczane są przez znikome nakłady na naukę. Sfera B+R oraz nowoczesnych technologii decyduje o sukcesie gospodarki opartej na wiedzy, a dystans w tym zakresie między najbardziej a najmniej uprzemysłowionymi regionami wynika ze skromnego zaplecza gospodarczego tych drugich. Ich aktualna sytuacja nie stwarza warunków dla rozwoju nowoczesnego 
przemysłu, a zdynamizowanie rozwoju w tych regionach w oparciu o rozwój nowych technologii jest zadaniem trudnym i nieprzynoszącym efektów w krótkim czasie.

Zasadniczą barierą przemian w regionach problemowych jest ich niewystarczająca zdolność do akumulowania impulsów rozwojowych bazujących na wiedzy i informacji. Ostrość problemu wynika przede wszystkim z niskiego poziomu wydatków na B+R, które przesądzają o braku perspektyw i dalszej marginalizacji tych regionów. Ważnym czynnikiem wzrostu w odniesieniu do obszarów problemowych jest polityka wyrównawcza, która powinna polegać na tworzeniu warunków do pełniejszego wykorzystania pozostających w bezczynności zasobów ludzkich, niewykorzystanego kapitału społecznego i infrastruktury, tak by umożliwić społecznościom obszarów mniej rozwiniętych partycypację w generowaniu dochodu narodowego, a nie tylko jego redystrybucji (Pastuszka, 2012: 94). Celem takiego podejścia nie jest oczywiście uzależnienie od pomocy publicznej, ale zainicjowanie długofalowych procesów rozwojowych na danym obszarze, ukierunkowanych na uruchomienie potencjału endogenicznego.

\section{INTERWENCJA EUROPEJSKIEJ POLITYKI REGIONALNEJ}

W ZAKRESIE WZMACNIANIA FUNKCJI PRZEMYSŁU

Fundamentalnym celem politycznym UE jest wzmocnienie jej konkurencyjności w gospodarce globalnej, co wiąże się z gotowością przeznaczania rosnącego poziomu alokacji z budżetu Unii. W tym kontekście można odnotować rosnące znaczenie polityki regionalnej, które jest widoczne przy porównaniu procentowej zmiany poziomu wydatków ponoszonego na jej prowadzenie. Przy czym największą zmianę - wzrost o blisko 64\% - odnotowano między perspektywami finansowymi 2000-2006 a 2007-2013. Warunkiem sprawnego funkcjonowania UE jako jednolitego mechanizmu gospodarczego jest zbliżony poziom rozwoju na całym obszarze, w przeciwnym razie następuje ograniczenie ogólnego potencjału rozwoju. Tymczasem efekty budowy wspólnego rynku i kolejne etapy pogłębiania procesu integracji w ramach UE rozkładały się asymetrycznie, w większym stopniu dotycząc regionów silnych. Dysproporcje w poziomie rozwoju poszczególnych regionów oraz potrzeba zrekompensowania biedniejszym regionom słabszych efektów wynikających z procesu integracji wymagają interwencji publicznej, która jest prowadzona na kilku poziomach: regionalnym, krajowym i europejskim. Działania podejmowane w ramach polityki regionalnej UE są ukierunkowane na wzmocnienie spójności gospodarczej, społecznej i terytorialnej poprzez zmniejszenie rozpiętości w poziomie rozwoju regionów i państw członkowskich Unii. Konieczność prowadzenia działań na rzecz poprawy spójności społeczno-ekonomicznej UE była akcentowana już w Traktatach Rzymskich. Szczególną jednak wagę do sfery rozwoju regionalnego Unia przywiązuje od czasów reformy Delors'a, rozpoczętej w 1989 roku. Od tego czasu UE programuje swoje polityki i budżet w wieloletnim horyzoncie czasowym. Dotychczasowe okresy dotyczyły lat: 1989-1993, 1994-1999, 2000-2006 oraz 2007-2013. Komisja Europejska jest zobowiązana do przedstawienia - co trzy lata - sprawozdania w sprawie postępów 
w urzeczywistnianiu spójności gospodarczej, społecznej i terytorialnej w formie tzw. raportów kohezyjnych. Dotychczasowe badania ewaluacyjne przeprowadzane przez Komisję w zakresie oddziaływania europejskiej polityki regionalnej na rozwój państw i regionów unijnych wskazują na jej wymierny udział w nadawaniu impulsów wzrostowych (Ulbrych, 2012).

Założenia teoretyczne oraz przesłanki omawianej polityki uległy modyfikacji wraz z podnoszeniem poziomu integracji oraz poszerzaniem składu członkowskiego Unii. Do lat 70. XX w. realizowana była koncepcja scentralizowanego paradygmatu rozwoju regionalnego, w myśl którego zadanie państwa polegało na wyrównywaniu dysproporcji w rozwoju przestrzennym za pośrednictwem redystrybucji środków budżetowych w przekroju międzyregionalnym. Działania państwa zorientowane były głównie w trzech kierunkach (Pietrzyk, 2004: 16-21):

- finansowanie inwestycji infrastrukturalnych w regionach opóźnionych w rozwoju;

- podejmowanie przez państwo na obszarach zacofanych budowy wielkich kompleksów przemysłowych (tzw. biegunów wzrostu) lub kierowanie do nich inwestorów;

- finansowanie deglomeracji czynnej dużych ośrodków przemysłowych.

W następstwie kryzysu strukturalnego gospodarek krajów wysoko rozwiniętych pod koniec lat 70., został zakwestionowany dotychczasowy model polityki regionalnej. Dezaktualizacji uległy bowiem założenia, na których był on oparty, w tym przede wszystkim względna stabilność warunków zewnętrznych i wewnętrznych oraz postępująca decentralizacja administracji. Równie ważne okazały się tendencje w ekonomii międzynarodowej w zakresie wzrostu znaczenia technologii i innowacji oraz serwicyzacja gospodarki i rosnąca rola małych i średnich przedsiębiorstw w aktywizowaniu zasobów pracy. Wymienione czynniki wywołały reorientację polityki regionalnej, której zasadniczym zadaniem stało się redukowanie potencjału rozwoju w regionach i stymulowanie dostosowań sektorowych i strukturalnych. Rozwój gospodarczy państwa zaczęto postrzegać natomiast jako wypadkową rozwoju jego składowych obszarów, stąd tak ważne jest wspieranie konkurencyjności regionów.

Ważnym aspektem jest równoczesne utrzymanie priorytetu konkurencyjności Unii na arenie międzynarodowej i spójności wewnętrznej. Dyskusja wokół preferowania spójności czy wzrostu stanowi poważny dylemat strategicznego ukierunkowania polityki regionalnej. Zasadnicze pytanie dotyczy obszaru interwencji nastawionego przede wszystkim na stymulowanie rozwoju gospodarczego, w tym budowania podstaw dla gospodarki opartej na wiedzy czy promowaniu rozwoju zrównoważonego, opierającego się na celach społecznych i ekologicznych. Kolejny problem to wybór pomiędzy działalnością prorozwojową a wyrównywaniem różnic społecznych i ekonomicznych między poszczególnymi regionami (Grosse, 2004). Potrzeba zmiany modelu wyrównawczego znajduje odzwierciedlenie w podejściu funkcjonalnym, które nie stoi w sprzeczności z dążeniem do konkurencyjności. U jego podstaw leży założenie sugerujące, że występowanie obszarów wzrostu oraz stagnacji jest naturalne i nie stanowi bariery dla procesu rozwoju, o ile skala zróżnicowania nie jest zbyt duża. Spójność rozumiana funkcjonalnie zachodzi w trzech wymiarach: ekonomicznym, społecznym i terytorialnym, a konkurencyjność obszaru definiuje się jako sumę konkurencyjności przedsiębiorstw oraz ich otoczenia (Churski, 2011). 
Polityka regionalna jest adresowana terytorialnie, a wsparcie w ramach funduszy strukturalnych (Europejskiego Funduszu Rozwoju Regionalnego - EFRR i Europejskiego Funduszu Społecznego - EFS) oraz Funduszu Spójności (FS) w niewielkim stopniu jest bezpośrednio skierowane na zwiększenie potencjału produkcyjnego. Współfinansowane są głównie przedsięwzięcia pośrednio wpływające na działalność produkcyjną poprzez rozbudowę infrastruktury technicznej oraz poprawę kwalifikacji kapitału ludzkiego. Podstawowym instrumentem finansowym europejskiej polityki spójności jest EFRR, w ramach którego finansowana jest pomoc na rzecz harmonijnego rozwoju UE poprzez wyrównywanie dysproporcji między poszczególnymi regionami oraz wspieranie przekształceń strukturalnych, w tym także upadających regionów przemysłowych.

Polityka regionalna skupia działania pomocowe na określonej liczbie priorytetów. Jej cele ulegały zmianie w kolejnych perspektywach finansowych, uwzględniając strategiczne wyzwania stojące przed UE. W latach 80. i 90. XX wieku w centrum zainteresowania omawianej polityki były tereny przemysłowe, ale perspektywa, a następnie akcesja krajów Europy Środkowo-Wschodniej do UE zdecydowała o koncentracji realizowanych programów na zapóźnionych regionach nowych krajów członkowskich.

W latach 2007-2013 polityka spójności, choć nadal służyła zmniejszeniu różnic pomiędzy regionami, w większym stopniu została podporządkowana priorytetom strategii lizbońskiej na rzecz zwiększenia działań zorientowanych na poprawę konkurencyjności wszystkich regionów UE. Zapewniała także znaczne wsparcie dla rekonwersji przemysłowej, obejmując szeroką gamę tematów, których współfinansowanie rozwijało infrastrukturę warunkującą działalność przemysłową (tab. 3). Należy jednak pamiętać, że zakres wsparcia i sposób oddziaływania na poszczególne państwa członkowskie wynika nie tylko z przydzielonej alokacji, ale także przyjętych priorytetów polityki wewnętrznej i efektywności władz lokalnych.

Tab. 3. Wsparcie polityki regionalnej UE dla rekonwersji przemysłowej w latach 2007-2013

\begin{tabular}{|l|c|c|c|}
\hline Obszar interwencji polityki regionalnej & EFRR & EFS & FS \\
\hline Infrastruktura transportowa i ochrona środowiska & $\mathrm{X}$ & & $\mathrm{X}$ \\
\hline Rewitalizacja terenów poprzemysłowych & $\mathrm{X}$ & & \\
\hline Wsparcie dla tworzenia/rozwoju MŚP & $\mathrm{X}$ & $\mathrm{X}$ & \\
\hline BiR oraz projekty innowacyjne & $\mathrm{X}$ & & \\
\hline Infrastruktura i usługi edukacyjne i szkoleniowe & $\mathrm{X}$ & $\mathrm{X}$ & \\
\hline Dostęp do zatrudnienia & & $\mathrm{X}$ & \\
\hline Lokalne inicjatywy na rzecz rozwoju & $\mathrm{X}$ & & \\
\hline Wzmocnienie zdolności instytucjonalnej & & $\mathrm{X}$ & \\
\hline Inne (kultura, turystyka, zdrowie i infrastruktura społeczna) & $\mathrm{X}$ & & \\
\hline
\end{tabular}

Źródło: Tödtling-Schönhofer, Davies (2013)

Budżet UE na lata 2014-2020 zakłada inwestycje w ramach polityki spójności w kwocie 325 mld euro w państwach członkowskich, ich regionach i miastach, by zostały osiągnięte cele w zakresie wzrostu gospodarczego i tworzenia nowych miejsc pracy, a także przeciwdziałania zmianie klimatu, zależności energetycznej i wykluczeniu społecznemu. Główne wytyczne nowego okresu programowania zakładają 10 prerogatyw, wśród 
których najistotniejsze z punktu widzenia analizowanej problematyki wydają się 3 pierwsze (MEMO/13/878):

1. Inwestowanie we wszystkich regionach UE, z uwzględnieniem poniższej typologii regionów: regiony słabiej rozwinięte (PKB $<75 \%$ średniej UE), regiony w okresie przejściowym $(75 \%<\mathrm{PKB}<90 \%$ średniej UE) oraz regiony lepiej rozwinięte (PKB $>90 \%$ średniej UE).

2. Kierowanie środków do kluczowych sektorów wzrostu, wśród których wyróżniono innowacje i badania, agendę cyfrową, małe i średnie przedsiębiorstwa oraz rozwijanie gospodarki niskoemisyjnej.

3. Ustalenie jasnych, przejrzystych i wymiernych celów oraz założeń w zakresie wyników i ich pomiaru.

Pozostałe priorytety dotyczą m.in.: opracowania wspólnej strategii na rzecz lepszej koordynacji i niwelacji powielania działań, co oznacza lepsze powiązanie pomiędzy funduszami strukturalnymi, inwestycyjnymi i innymi instrumentami finansowymi UE. Zwraca się także uwagę na ograniczenie biurokracji i uproszczenie zasad korzystania z inwestycji UE dzięki wspólnym zasadom odnoszącym się do wszystkich europejskich funduszy oraz wzmocnienie miejskiego wymiaru polityki i współpracy granicznej.

Tab. 4. Wartość dostępnej alokacji w ramach polityki regionalnej w latach 2014-2020 (mln euro)

\begin{tabular}{|c|c|c|c|c|c|c|c|}
\hline \multirow[b]{2}{*}{ Kraj } & \multirow[b]{2}{*}{ 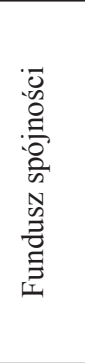 } & \multicolumn{4}{|c|}{ EFRR i EFS } & \multirow[b]{2}{*}{ 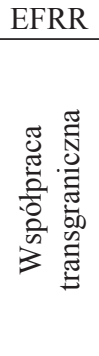 } & \multirow[b]{2}{*}{$\begin{array}{l}\frac{E}{0} \\
\frac{0}{0} \\
0 \\
0\end{array}$} \\
\hline & & 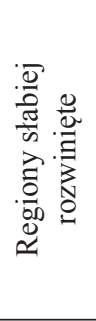 & 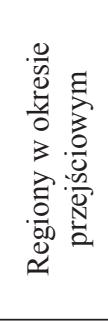 & 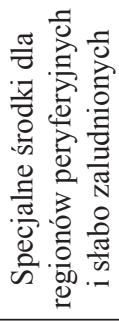 & 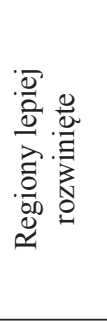 & & \\
\hline Austria & - & - & 66 & - & 823 & 226 & 1114 \\
\hline Belgia & - & - & 962 & - & 868 & 231 & 2061 \\
\hline Bułgaria & 2384 & 4623 & - & - & - & 145 & 7153 \\
\hline Chorwacja & 2676 & 5225 & - & - & - & 128 & 8029 \\
\hline Cypr & 286 & - & - & - & 388 & 29 & 703 \\
\hline Czechy & 6562 & 13646 & - & - & 79 & 298 & 20585 \\
\hline Dania & - & - & 64 & - & 230 & 199 & 494 \\
\hline Estonia & 1123 & 2198 & - & - & - & 49 & 3369 \\
\hline Finlandia & - & - & - & 272 & 911 & 142 & 1325 \\
\hline Francja & - & 3147 & 3927 & 395 & 5862 & 956 & 14288 \\
\hline Grecja & 3407 & 6420 & 2105 & - & 2307 & 203 & 14443 \\
\hline Hiszpania & - & 1858 & 12201 & 432 & 10084 & 542 & 25116 \\
\hline Holandia & - & - & - & - & 908 & 342 & 1250 \\
\hline Irlandia & - & - & - & - & 869 & 148 & 1017 \\
\hline Litwa & 2145 & 4189 & - & - & - & 100 & 6434 \\
\hline Luksemburg & - & - & - & - & 39 & 18 & 57 \\
\hline Łotwa & 1412 & 2742 & - & - & - & 82 & 4236 \\
\hline Malta & 228 & - & 441 & - & - & 15 & 684 \\
\hline
\end{tabular}




\begin{tabular}{|l|r|r|r|r|r|r|r|}
\hline Niemcy & - & - & 8750 & - & 7609 & 847 & 17207 \\
\hline Polska & 24274 & 45917 & - & - & 2017 & 615 & 72823 \\
\hline Portugalia & 3000 & 15008 & 232 & 103 & 1148 & 108 & 19599 \\
\hline Rumunia & 7251 & 13773 & - & - & 405 & 397 & 21826 \\
\hline Słowacja & 4361 & 8489 & - & - & 40 & 196 & 13086 \\
\hline Słowenia & 939 & 1134 & - & - & 763 & 55 & 2891 \\
\hline Szwecja & - & - & - & 184 & 1355 & 300 & 1840 \\
\hline Węgry & 6313 & 13452 & - & - & 416 & 318 & 20498 \\
\hline $\begin{array}{l}\text { Wielka } \\
\text { Brytania }\end{array}$ & - & 2126 & 2335 & - & 5144 & 760 & 10364 \\
\hline Włochy & - & 20333 & 1004 & - & 7006 & 998 & 29341 \\
\hline
\end{tabular}

Źródło: European Commission (2013, 30 listopada)

Analizując skalę dostępnej alokacji w ramach polityki regionalnej w latach 2014-2020, można zauważyć, że wciąż największa część (51\%) jest zagwarantowana dla regionów słabiej rozwiniętych, natomiast dla regionów lepiej rozwiniętych przeznaczono 15\% dostępnych środków (tab. 4). Kluczowym elementem działań UE ukierunkowanych na udzielenie regionom pomocy w wypracowywaniu własnej ścieżki rozwoju jest tzw. inteligentna specjalizacja. Polega ona na wprowadzaniu selektywnych inwestycji w regiony w celu poszukiwania dla nich niszy przemysłowej i technologicznej na światowym rynku. Opracowanie strategii badawczych i innowacyjnych opartych na tej koncepcji należy do warunków koniecznych dla uzyskania wsparcia z funduszy strukturalnych (Komisja Europejska, 2012).

Zorientowanie polityki regionalnej na budowanie siły konkurencyjnej regionów oraz jej inwestycyjny charakter wzmacniają skuteczność działań w zakresie rozwoju przemysłu. Strategicznym zadaniem regionów problemowych jest możliwie duża absorpcja unijnych funduszy i maksymalizacja efektu ekonomicznego podjętych przedsięwzięć. Istotnym problemem i barierą w pozyskiwaniu środków w przypadku najsłabiej rozwiniętych regionów pozostaje jednak ich słabość gospodarcza i instytucjonalna.

\section{WNIOSKI}

Przeprowadzona analiza pozwala na przedstawienie podstawowych prawidłowości w kontekście zróżnicowania przestrzennego działalności przemysłowej w UE. Obraz regionalnego zróżnicowania poziomu uprzemysłowienia podkreśla różnice w zakresie aktywności przemysłowej, które nawiązują do historycznie ukształtowanej osi rozwoju społeczno-gospodarczego Europy.

Dotychczasowa organizacja produkcji ustępuje miejsca zdolnościom innowacyjnym, a celem UE i jej regionów jest wspieranie przemysłu we wdrażaniu rozwiązań nowatorskich. Pobudzanie inwestycji, zarówno w początkowych fazach wprowadzania, jak i upowszechniania nowych technologii, wymaga wypracowania stosownych przepisów technicznych i zasad funkcjonowania rynku wewnętrznego oraz towarzyszącej im infrastruktury. Negatywny wpływ kryzysu na szereg państw członkowskich UE oraz pogarszające się perspektywy dla 
gospodarki światowej zrodziły potrzebę podjęcia aktywnych działań w kierunku konkurencyjnej gospodarki, uwzględniającej aspekt społeczny i środowiskowy. Wiodącym sektorem stymulującym wzrost gospodarczy jest bardziej efektywny przemysł bazujący na potencjale kapitału ludzkiego. Świadomość znaczenia stymulowania rozwoju wydaje się podstawą konceptualizacji zakresu interwencji publicznej. Przedstawiony zarys oddziaływania europejskiej polityki regionalnej w sferze działalności przemysłowej pozwala stwierdzić, że jest ona istotnym narzędziem wspierającym zarówno obszary znajdujące się w niekorzystnej sytuacji, jaki i regiony lepiej rozwinięte. Uwzględnienie specyfiki terytorialnej w konfrontacji z dotychczasowymi praktykami umożliwia określenie priorytetów rozwojowych przez administrację regionalną. Istotnym warunkiem właściwego identyfikowania celów strategicznych jest promowanie podstawowych zasad polityki regionalnej, w tym przede wszystkim zasady koordynacji i partnerstwa. Obie zasady dotyczą kilku wymiarów relacji, chodzi jednak głównie w pierwszym przypadku o zintegrowane wykorzystanie wszystkich dostępnych instrumentów finansowych, w drugim natomiast o partnerstwo instytucjonalne i publiczno-prawne. Działania podejmowane przez władze na poziomie regionalnym i lokalnym w zakresie funkcjonowania przemysłu powinny opierać się na umiejętności efektywnego wykorzystania dostępnych instrumentów finansowych, w tym na absorbowaniu środków dostępnych w ramach polityki regionalnej UE. Determinujące znaczenie ma także kreowanie sieci powiązań między władzami publicznymi a podmiotami gospodarczymi i organizacjami społecznymi.

\section{Literatura \\ References}

Barca, F. (2009). An agenda for a reformed Cohesion policy: A place-based approach to meeting European Union challenges and expectations. Independent Report for D. Hübner, Commissioner for Regional Policy. Brussels.

Churski, P. (2011). Spójność a przestrzeń - dylematy polityki regionalnej. W: L. Mierzejewska, M. Wdowicka (red.). Problemy rozwoju lokalnego i regionalnego na początku XXI wieku. Biuletyn Instytutu Geografii Społeczno-Ekonomicznej i Gospodarki Przestrzennej UAM. Seria Rozwój Regionalny i Polityka Regionalna, 15, 99-108.

Dej, M., Domański, B., Działek, J., Gwosdz, K., Sobala-Gwosdz, A. (2011). Znaczenie przemystu dla ,inteligentnego i trwatego" rozwoju regionu Polski Wschodniej oraz podejmowanych dzialań dotyczacych jego restrukturyzacji i modernizacji. Ekspertyza przygotowana na zlecenie Ministerstwa Rozwoju Regionalnego. Kraków.

European Commission (2012). Communication from the Commission to the Parliament, the Council, the European Economic and Social Committee and the Committee of the regions: A Stronger European industry for Growth and Economic Recovery. Industrial Policy Communication Update. COM (2012) 582 final.

European Commission (2013, 30 listopada). Financial programming and budget. Pozyskano z http:// ec.europa.eu/budget/mff/preallocations/index_en.cfm.

European Commission (2013). Refocusing EU Cohesion Policy for Maximum Impact on Growth and Jobs: The Reform in 10 points, MEMO/13/878 07/11/2013.

Eurostat (2013, 30 listopada). Gross value added at basic prices by NUTS 3 regions oraz Population on 1 January by age and sex - NUTS 2 regions. Pozyskano z http://epp.eurostat.ec.europa.eu/. 
Eurostat (2013, 30 listopada). Regional gross domestic product (PPS per inhabitant in\% of the EU27 average) by NUTS 2 regions. Pozyskano z http://epp.eurostat.ec.europa.eu/.

Eurostat (2013, 30 listopada). Total intramural R\&D expenditure (GERD) by sectors of performance and NUTS 2 regions $i$ Human resources in science and technology (HRST) by NUTS 2 regions. Pozyskano z http://epp.eurostat.ec.europa.eu/.

Gorzelak, G. (2007). Rozwój - region - polityka. W: G. Gorzelak, A. Tucholska (red.). Rozwój, region, przestrzeń. Warszawa: Ministerstwo Rozwoju Regionalnego-EUROREG, 179-214.

Grosse, T.G. (2004). Wyzwania polityki rozwoju regionalnego w Polsce. Międzynarodowy Przeglad Polityczny, 1(6), 188-199.

Komisja Europejska (2010). Europa 2020. Strategia na rzecz inteligentnego i zrównoważonego rozwoju sprzyjającego właczeniu społecznemu. KOM (2010) 2020.

Komisja Europejska (2012). Panorama, 44.

Pastuszka, S. (2012). Polityka regionalna Unii Europejskiej - cele, narzędzia, efekty. Warszawa: Difin.

Pelkmans, J. (2006). European Industrial Policy. Bruges European Economic Policy Briefings (BEEP) briefing no 15. Pozyskano z https://www.coleurope.eu/sites/default/files/research-paper/beep15. pdf.

Pietrzyk, I. (2004). Polityka regionalna Unii Europejskiej i regiony w państwach członkowskich. Warszawa: Wydawnictwo Naukowe PWN.

Rachwał, T., Wiederman, K., Kilar, W. (2009). Rola przemysłu w gospodarce układów regionalnych Unii Europejskiej. Prace Komisji Geografii Przemystu Polskiego Towarzystwa Geograficznego, $14,31-42$.

Tödtling-Schönhofer, H., Davies, S. (2013). Regional Strategies for Industrial Areas. European Parlament: IP/B/REGI/FWC/2010-002/LOT1-C01-SC08.

Ulbrych, M. (2012). Zróżnicowanie poziomu rozwoju regionalnego w Polsce na tle Unii EuropejskiejPiąty Raport KE na temat spójności gospodarczej, społecznej i terytorialnej. W: E. Kolendowski (red.). Integracja regionalna wobec wyzwań wspótczesnej gospodarki światowej. Warszawa: Difin, 134-158.

Wieloński, A. (1998). Od industrializacji do reindustrializacji. Warszawa: Uniwersytet Warszawski. Wydział Geografii i Studiów Regionalnych.

Wren, C., Taylor, J. (1999). Industrial Restructuring and Regional Policy. Oxford Economic Papers, 51(3), 487-516.

Marta Ulbrych, dr. Zainteresowania naukowe autorki koncentrują się wokół procesów globalizacji i regionalizacji gospodarki światowej. Analizuje zagadnienia z zakresu międzynarodowej integracji gospodarczej i jej praktycznej realizacji, roli polityki przemysłowej w erze globalizacji, przekształceń społeczno-ekonomicznych gospodarki Turcji oraz rozwoju regionalnego w Polsce.

Marta Ulbrych, Ph.D. The author's research interests focus on the processes of globalisation and regionalisation of the world economy. In her research she examines the issues of international economic integration and its practical implementation, the role of industrial policy in the globalisation era, socio-economic transformation of the Turkish economy and regional development in Poland.

\section{Adres/address:}

Uniwersytet Ekonomiczny w Krakowie

Katedra Międzynarodowych Stosunków Gospodarczych

Zakład Studiów Regionalnych

ul. Rakowicka 27, 31-510 Kraków, Polska

www.uek.krakow.pl

e-mail: ulbrychm@uek.krakow.pl 